\title{
Chronic Amebiasis Presenting As Appendicitis and Preliminary Diagnosed As a Mucocele: A Diagnostic Dilemma and Unexpected Histopathological Finding After Surgery
}

Apandisit Kliniği ile Başvuran ve Mukosel Ön-Tanısı Alan Kronik Amebiasis: Tanısal Ikilem ve Cerrahi Sonrası Beklenmedik Histopatolojik Bulgu

\author{
Mehmet Tolga Kafadar ${ }^{1 *}$, Vedat Bakan ${ }^{2}$, Tuğba Çaviş ${ }^{3}$ \\ ${ }^{1}$ Health Sciences University Mehmet Akif Inan Training and Research Hospital Clinic of General Surgery, Sanluurfa, \\ Turkey \\ ${ }^{2}$ Esenler Obstetrics Gynecology and Pediatric Hospital Clinic of Pediatric Surgery Istanbul, Turkey \\ ${ }^{3}$ Atatürk Training and Research Hospital Clinic of Radiology, Ankara, Turkey
}

\begin{abstract}
Amoebic appendicitis is an extremely rare condition which is generally surgically treated with the initial diagnosis of acute appendicitis, and its definitive diagnosis cannot be made until the exact histopathological analysis. In this paper a 14-year-old male patient with amoebic appendicitis is presented. Pain in right lower quadrant was the only positive finding. A laparoscopic appendectomy was performed because of enlargement appendix and a preliminary diagnosis of mucocele in radiological examinations. Macroscopically appendix was extremely edematous and dilated. Microscopic analysis was evaluated as amoebic appendicitis. This case report emphasizes the importance of careful histopathological analysis of appendix, especially, in patients who do not demonstrate typical clinical symptoms of appendicitis. Timely diagnosis and appropriate therapy might prevent probable future complications in patients with amoebic appendicitis.
\end{abstract}

Key Words: Amebiasis, appendicitis, mucocele

\section{Introduction}

Appendicitis is the most common pathology requiring urgent abdominal operation in childhood and it develops as a result of obstruction and inflammation of the appendix lumen. Multiple parasitic infections originating from the digestive system may cause the development of acute appendicitis symptoms. However, parasitic infections are rarely among the causes of appendicitis in developed countries (1). Amebic appendicitis is an intestinal involvement type of invasive amebiasis which is rarely observed. Although the prevalence of amebiasis is reported 0.5-

\section{ÖZET}

Amebik apandisit son derece nadir görülen bir durumdur ve genellikle akut apandisit ön tanısı ile opere edilip histopatolojik incelemesi yapilıncaya kadar da tanısı konulamaz. Amebik apandisit tanısı alan 14 yaşında bir erkek hasta nadir görülmesi ve konuya dikkat çekilmesi amaciyla sunuldu. Hastada pozitif muayene bulgusu olarak sadece karın sağ alt kadran ağrısı mevcuttu. Radyolojik incelemelerdeki genişlemiş apendiks ve mukosel ön tanisı nedeniyle laparoskopik apendektomi uygulandi. Makroskopik olarak apendiks ödemli ve dilate idi. Mikroskopik inceleme amebik apandisit olarak yorumlandi. Bu olgu sunumu, özellikle tipik apandisit bulguları olmayan hastalarda dikkatli histopatolojik incelemenin önemini vurgulamaktadır. Zamanında tanı ve uygun tedavi ile, amebik apandisitli hastalarda olası komplikasyonlar önlenebilecektir.

Anahtar Kelimeler: Amebiyazis, apandisit, mukosel

$2.3 \%$ in the regions considered endemic based on the studies, $30.7 \%$ of the amebic appendicitis cases are complicated appendicitis and its mortality rate is higher than those who are non-amebic (2). A rare case with chronic appendicitis secondary to amebiasis was presented in this article to draw attention to the issue.

\section{Case Report}

A 14-year-old male patient was admitted in our outpatient clinic due to the complaints of abdominal pain and nausea. The right lower abdominal quadrant was associated with 
tenderness induced by palpation during the physical examination. The patient was admitted to a private hospital and a university hospital 3 weeks ago with suspicion of appendicitis. Depending on ultrasonographic examinations of both hospitals he was hospitalized in the pediatric inpatient clinic of the last visited university hospital and was administered treatment during 4-day stay (I.V. hydration, Ampicillin + Sulbactam, Amikacin sulfate and Ornidazole). He was told he has an amoeba disease while discharging, and that the patient taken Ornidazole for 1 week. The patient had leukocytosis depending on the laboratory tests, and his acute phase reactants, other biochemistry parameters and tumor markers were found normal. Based on the abdominal ultrasonography (US), the calibration of appendix vermiform reached to $5.6 \mathrm{~mm}$ in proximal and 15 $\mathrm{mm}$ in distal, periappendiceal fluid was observed and the periappendiceal mesentery tissue was severely edematous, and these findings were significant for perforation (Figure 1). In addition, multiple mesenteric lymph nodes with greatest dimensions of $12 \times 5 \mathrm{~mm}$ were identified. The patient was hospitalized and a conservative follow-up started because the clinical and laboratory findings of the patient were not consistent with appendicitis. Complaints and tenderness of the right lower abdominal quadrant were still present next day and control abdominal US reported that the expansion of appendix was consistent with mucocele in addition to the previous ultrasound findings. A contrasted abdominopelvic tomography (CT) was performed. Based on the $\mathrm{CT}$, a hypodense cystic formation (appendix mucocele?) with opaque wall following infusion of I.V. contrast agent, in dimensions of 40x15 mm was observed and that there were hyperdensity of mesenteric adipose tissue nearby cecum (Figure 2). Operation was decided for the patient and intravenous (I.V.) metronidazole 30 $\mathrm{mg} / \mathrm{kg} / \mathrm{day}$ and I.V. Ceftriaxone $75 \mathrm{mg} / \mathrm{kg} /$ day started administering as prophylactic. A laparoscopic appendectomy was performed by means of linear stapler according to the preliminary diagnoses of appendicitis and mucocele, in a way that the entire appendix tissue will be excised and with excision of 3-4 $\mathrm{mm}$ from the cecum wall. As a result of examination of the piece taken out of the abdomen without rupturing it, by frozen section, the operation was terminated because no finding was observed that would suggest mucocele or another malignant condition.

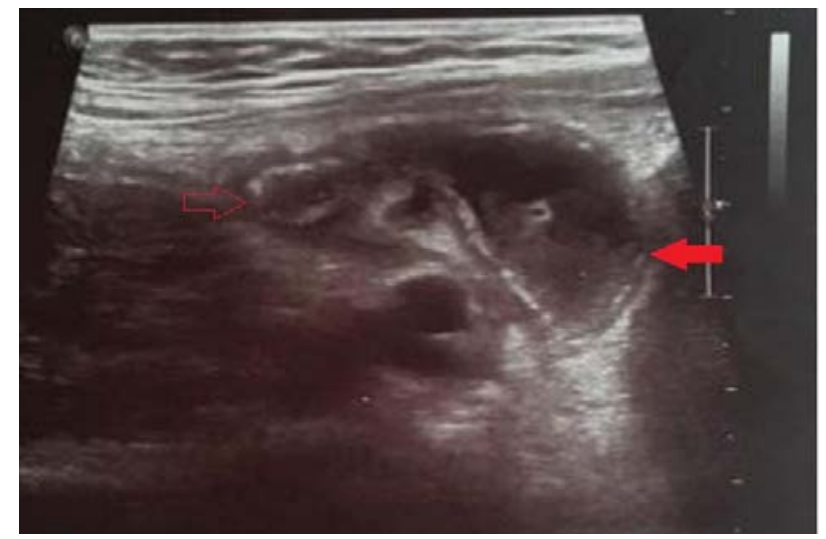

Fig. 1. On the ultrasonographic imaging, appendix vermiformis of which calibration was measured 5.6 $\mathrm{mm}$ in the proximal segment (hollow arrow) and 15 $\mathrm{mm}$ in the distal segment (solid arrow), with thick wall and edematous, lumen is full of fluid echogenicity, and edematous image of the mesentery.
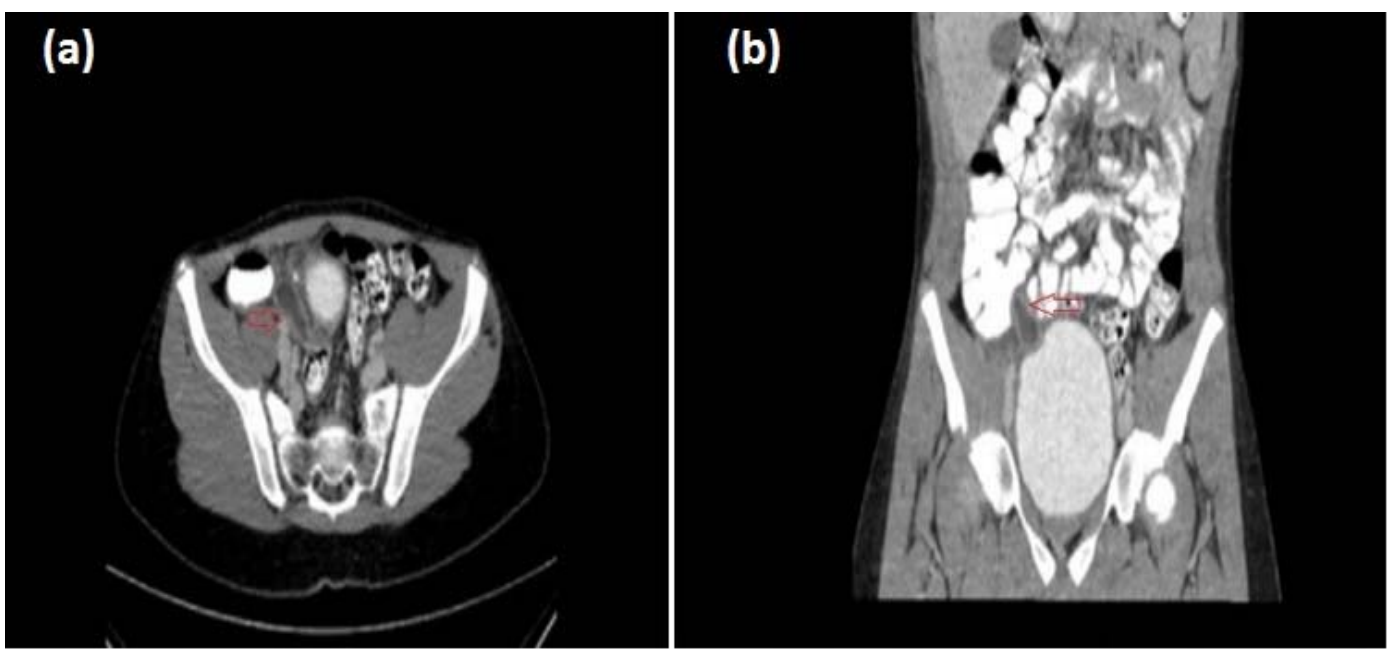

Fig. 2. Preoperative CT scan showing a hypodense cystic formation on the axial (a) and coronal (b) sequences, in dimensions of $40 \times 15 \mathrm{~mm}$ in medial of the cecum, with opaque wall (3 $\mathrm{mm}$ ) following infusion of I.V. contrast agent (appendix mucocele?). 

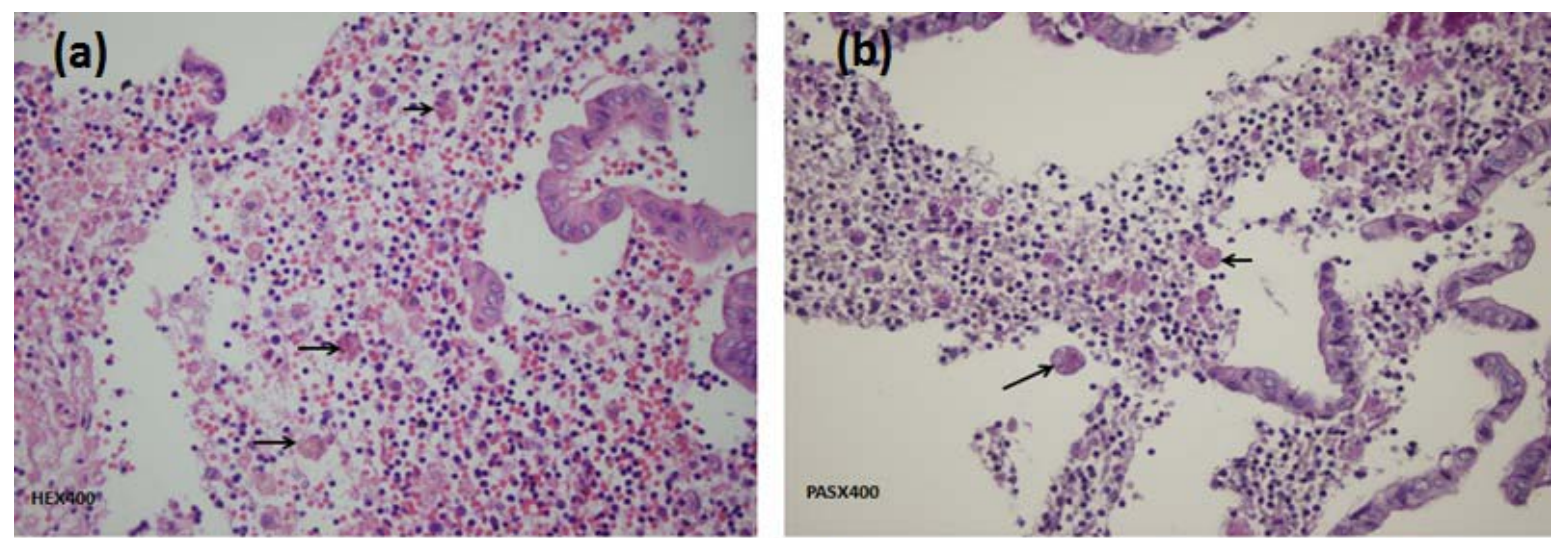

Fig. 3. Images in the areas with chronic inflammation and mucosal ulceration of appendix and periappendiceal adipose tissue, much larger than histiocytes, with a single nucleus with thin chromatin and consistent with amoeba trophozoites staining PAS-positive indicating erythrophagocytosis (a) H\&E:400x (b) PAS:400x.

Histopathological examination of the patient was reported as amebiasis since appendix and periappendiceal adipose tissue were with chronic inflammation and the Periodic Acid-Schiff (PAS)positive structures greater than histiocytes in the mucosal ulceration areas with a single nucleus with thin chromatin and indicating erythrophagocytosis were found consistent with Entamoeba Histolytica trophozoites (Figure 3). Ceftriaxone was stopped on post-operative day 3 and the patient was discharged. The treatment of Metronidazole (30 $\mathrm{mg} / \mathrm{kg} /$ day in three doses) prescribed for amoeba was completed to 10 days by oral route after the patient discharged. The patient had no complaint during the post-operative follow-up period of one year. Informed consent was obtained from the father of the patient who participated in this case.

\section{Discussion}

Appendicitis is one of the most common causes for operation in children. It frequently occurs as a result of obstruction of the appendix lumen for non-specific causes. Other accused etiologic factors include petrified feces, undigested foods, foreign bodies, enlarged lymph nodes, turning of the organ around itself and parasites. And less frequently, enteric pathogens might directly infect the appendix. And reported microorganisms are adenovirus, rubeola virus (measles), Epstein-Barr virus and Actinomyces Israeli (Actinomycosis). In $0.2-41.8 \%$ of patients with appendicitis syndromes, parasite infection was diagnosed also. In $0.45-3.1 \%$ of the appendix pieces operated in Turkey and in 1.5\% of patients in Brazil, parasite was reported according to the study conducted by Da Silva et al $(1,3)$.
Amebiasis is a parasitic infection caused by amoeba called Entamoeba Histolytica (EH). 80$99 \%$ of the individuals infected by this parasite are asymptomatic. Amebiasis may be confronted with different clinical pictures including extraintestinal and intestinal. The intestinal amebiasis may be asymptomatic, or it may be in the form of acute or chronic intestinal involvement with abdominal pain and diarrhea with hemorrhagic mucous. Clinically, there may be a clinical course that varies from mild colitis and hemorrhagic dysentery to toxic megacolon, colon perforation and peritonitis. Perforation and peritonitis emerging as a result of fulminant colitis and intestinal necrosis are observed in $0.5 \%$ of patients and the mortality rate of these patients is above $40 \%$ (4). In a series of amebic appendicitis reported from Japan, postoperative intraabdominal severe complication rate reported as $37 \%$, and the mortality rate reported as $25 \%$ (2). Amebic colitis might be diagnosed also in asymptomatic patients. In a study conducted in Japan, colonoscopy performed in 5193 individuals who are occult blood-positive in the stool and amebic ulcerative lesions of the cecum and ascending colon diagnosed in four patients (5). Granulation tissue mass that is developing as a result of localized infection of the colon and called ameboma is a clinical condition observed very rare and it is usually diagnosed during physical examination as a sensitive palpable abdominal mass (6).

Amebic appendicitis is also an invasive intestinal involvement form observed very rare and it is deemed as a cause of acute appendicitis observed rarely. EH can be accepted as an etiologic factor when considering that appendicitis emerges as a result of obstruction of the appendix lumen. 
Acute appendicitis clinic of the patient may be seen when infection is developed as a result of obstruction of the lumen. It should also be kept in mind that intestinal amebiasis may mimic the symptoms of appendicitis and negative appendectomy may be performed in these patients. Therefore, amebic colitis should always be remembered in the differential diagnosis of acute appendicitis (7). It is a question facing us that must be answered if the association of appendicitis and amebiasis is a causal relationship or is a coincidence. Other causes of acute amebic appendicitis do not present a different clinical condition and diagnosis is made by histopathologic imaging of amoebic trophozoites (8). Diarrhea is not primary in these cases. Abdominal pain is usually accompanied by fever. The lack of fever in our case may be due to the fact that he has been treated before. Contrary to the cases and series published in the literature, being chronic appendicitis for our patient is important in terms of contribution to the literature.

Pre-operative diagnosis of amebic appendicitis is almost impossible because there is no any available laboratory test or clinical feature other than stool examination, which would help to differentiate appendicitis occurred secondary to other etiologies from amebic appendicitis (9). Ciftci et al. (7) reported in their study involving 482 patients with intestinal amebiasis, that complicated amebiasis developed in 18 (3.7\%) patients. They found perforated appendicitis in 4 and negative abdominal exploration and normal appendix in three of these complicated 18 patients. Both intestinal amebiasis was diagnosed histopathologically and amoeba trophozoites were found in all of these three patients with negative appendectomy. In stool microscopy, diagnosis can be made in the rate of $85-90 \%$ as a result of examination of at least 3 stool specimens obtained in different days, preferably in a period with fever attack by experienced individuals using specific methods. Clinical management of parasitic infestations is different than that of classical appendicitis. Metronidazole must be added to the treatment following appendectomy for the treatment of amebiasis. Morbidity and mortality rates are increased in the post-operative period following appendectomy when oral Metronidazole treatment is delayed (9).

Appendix mucocele it is characterized by dilatation of the appendix lumen due to abnormal mucus accumulation. This lesion observed rarely has no typical clinical course and its pre-operative diagnosis is difficult to make. Diagnosis is usually made incidentally during pre-operative abdominal imaging studies or during operations performed due to another cause (10). Rate of incidence of appendix mucocele in appendectomy pieces is reported as $0.2-0.3 \%$. Approximately $25-30 \%$ of patients are symptomatic and it is diagnosed incidentally during radiological studies, endoscopic examinations and during operation. It is observed on ultrasonographic imaging as encapsulated lesions, with regular contour, adjacent to the cecum, with layers similar to onionskin and with internal echogenicities. Mucocele is usually hypoechogenic on US imaging. However, echogenicity may also be seen depending on the amount of acoustic interfaces formed by mucus; a posterior acoustic enhancement is usually present. It may contain debris and septa, and there may be papillary protuberances on its wall sometimes secondary to mucosal proliferation. Apart from acute appendicitis, the mucocele wall is usually thin and dystrophic calcifications may be observed secondary to chronic inflammation. No peripheral inflammation or abscess is observed in case of it is not perforated. On CT, it may be seen as a round mass, with low-density and thin wall, encapsulated, and associated with the cecum (11).

In conclusion; all the appendices removed by surgery should be examined for histopathological diagnosis. In this way, prevention of morbidity and mortality would be possible with appropriate treatment by diagnosing the factors imitating appendicitis and mucocele on the imaging without delay, such as amoeba that is extraordinarily observed rare in the etiology of appendicitis.

Informed Consent: Informed consent was obtained from the father of the patient.

Conflict of Interest: No conflict of interest was declared by the authors.

Financial Disclosure: The authors declared that this study has received no financial support.

\section{References}

1. da Silva DF, da Silva RJ, da Silva MG, Sartorelli AC, Rodrigues MA. Parasitic infection of the appendix as a cause of acute appendicitis. Parasitol Res 2007; 102(1): 99-102.

2. Ito D, Hata S, Seiichiro S, Kobayashi K, Teruya M, Kaminishi M. Amebiasis presenting as acute appendicitis: Report of a case and review of Japanese literature. Int J Surg Case Rep 2014; 5(12): 1054-1057. 
3. Aydin O. Incidental parasitic infestations in surgically removed appendices: a retrospective analysis. Diagn Pathol 2007; 2: 16.

4. Otan E, Akbulut S, Kayaalp C. Amebic acute appendicitis: systematic review of 174 cases. World J Surg 2013; 37(9): 2061-2073.

5. Okamoto M, Kawabe T, Ohata K, Togo G, Hada $\mathrm{T}$, Katamoto $\mathrm{T}$, et al. Amebic colitis in asymptomatic subjects with positive fecal occult blood test results: clinical features different from symptomatic cases. Am J Trop Med Hyg 2005; 73(5): 934-935.

6. Misra SP, Misra V, Dwivedi M. Ileocecal masses in patients with amebic liver abscess: etiology and management. World J Gastroenterol 2006; 12(12): 1933-1936.

7. Ciftci AO, Karnak I, Senocak ME, Kale G, Büyükpamukçu N. Spectrum of complicated intestinal amebiasis through resected specimens: incidence and outcome. J Pediatr Surg 1999; 34(9): 1369-1373.

8. Dorfman S, Cardozo J, Dorfman D, Del Villar A. The role of parasites in acute appendicitis of pediatric patients. Invest Clin 2003; 44(4): $337-$ 340.

9. Ilikkan DY, Ilikkan B, Vural M. Amebiasis in infancy in the middle-high socioeconomic class in Istanbul, Turkey. Pediatr Infect Dis J 2005; 24(10): 929-930.

10. Shukunami K, Kaneshima M, Kotsuji F. Preoperative diagnosis and radiographic findings of a freely movable mucocele of the vermiform appendix. Can Assoc Radiol J 2000; 51(5): 281282.

11. Pickhardt PJ, Levy AD, Rohrmann CA Jr, Kende AI. Primary neoplasms of the appendix: radiologic spectrum of disease with pathologic correlation. Radiographics 2003; 23(3): 645-662. 